\title{
Understanding the Adoption of Electronic Banking in China
}

\author{
Sherah Kurnia, Fei Peng, Yi Ruo Liu \\ The University Of Melbourne \\ Sherahk@unimelb.edu.au
}

\begin{abstract}
Electronic banking (e-banking), facilitated by various Electronic Commerce (EC) technologies, has helped commercial banks to stay competitive through productivity gains, transaction cost reduction and customer service improvement. Despite its benefits, however, developing countries still lag behind developed countries in the adoption of e-banking. To address the lack of studies on e-banking adoption in developing countries, this paper explores factors impacting e-banking adoption in China, as an example of a developing country. Facing an intense competition from foreign-owned banks, Chinese domestic banks have recently been actively engaged in e-banking initiatives. A research framework developed based on technology-organizational-environmental framework is used to guide the study. The findings from this study involving one of the four state-owned banks complement the existing knowledge in this area to better understand the adoption and development of $e$ banking in China.
\end{abstract}

\section{Introduction}

Electronic banking has triggered massive change in the commercial banking practices since it was first introduced as "home banking" services by the four major New York banks in 1981 [1]. While there are differing definitions related to e-banking found in the literature, in this study, e-banking refers to performing banking transactions using electronic medium. It covers various initiatives such as Internet banking, Internet payment system, phone banking, and mobile banking, to name a few. It enables customers to perform banking transactions without visiting a brickand-mortar banking institution. Capitalising on eCommerce's (EC) ability to offer productivity gains, transaction cost reductions, improved customer services and flexibility in fulfilling customers' changing needs and lifestyles, e-banking has enabled banking institutions to compete more effectively in this global environment, extending their products and services beyond the restriction of time and space [2].

However, mirroring the development of ecommerce, the adoption and diffusion of e-banking is far from uniform, especially between the developed and developing worlds [3]. The developed countries have experienced widespread e-banking use and enjoyed its many benefits [4]. On the other hand, the developing countries has just started to embrace the concept of e-banking in recent years [1]. It is believed that in the long run, developing countries could benefit more from e-banking than developed countries since they could leap frog their technology development by learning from the experiences of the developed nations [5]. However, during this development processes, it is expected that the developing countries will face many unexpected and complex factors that inhibit the speed and scale of e-banking adoption [6].

In order to encourage further e-banking adoption in developing countries, a better understanding of the drivers and barriers impacting e-banking adoption is critical [4]. By gaining an in-depth understanding of the factors and conditions that influence developing country's ability to fully adopt and realise its benefits, strategic implications can be generated for the researchers and practitioners regarding how to promote the growth of e-banking in the developing countries. However, despite the importance of these adoption studies in developing countries, limited studies are currently available $[3,4,7,8]$. Therefore, more studies are still required to understand the relevance of ebanking in developing countries and to identify areas the developing countries lag behind which inhibit their e-banking adoption and diffusion.

To address the current gap in the literature, this research project is designed to assess the e-banking adoption situation in People's Republic of China, as an example of a developing country. The research questions addressed are:

1. What are the drivers for e-banking adoption in China? 2. What are the barriers to e-banking adoption in China?

China is chosen as an example of a developing country because of its unique position and condition. It has experienced a rapid economic development with an annual GDP growth rate of about $10 \%[4,7]$. Furthermore, China's economic power, market potential, and infrastructure development through various Golden Projects particularly the Golden Card Projects to develop e-banking in China provide a rich 
ground for e-banking growth [4]. Furthermore, China's relatively immature technical, legal and e-commerce infrastructures make it a representative case for developing countries $[4,6]$.

Specifically, a domestic state-owned bank in China was chosen as the context of the study for a number of reasons. Firstly, Chinese banking industry is not generally well understood since it had enjoyed a strong government protection from foreign competitors over a long period of time [4]. Currently, there are still limited studies about the adoption of e-banking by Chinese domestic banks [7]. Choosing one of the big four stateowned domestic banks reflects the mainstream banking practices in China. These state-owned banks control the majority of market share in China's banking sector and enjoy abundant resources. Therefore, they are in a position to engage in various EC initiatives including e-banking development and their experiences will consequently provide us with a rich picture of ebanking adoption in China [9]. Furthermore, although e-banking is widely known as an effective strategy to compete in the market, well-established domestic banks in China are often considered rather conventional in carrying out business processes and following the long-standing tradition [7]. Therefore, a better understanding of the adoption of e-banking particularly the key drivers and barriers through an indepth study of a Chinese domestic bank will enrich the existing knowledge in this area.

This study is built upon the previous recent studies on e-banking adoption in China that are currently limited in number [3]. Lu et al. [7] explore four factors affecting the Internet banking investment by banks in China through a survey study. The understanding obtained is limited by the nature of quantitative study that generally lacks in depth and the limited factors investigated [44]. Other studies [3, 4] assess e-banking from the consumers' point of view and hence the findings are limited to consumers' behavior and perception towards e-banking.

To complement the previous studies, in this study we use the technology-organization-environment (TOE) framework of Tornatzky and Fleischer [18] to help identify a more complete set of factors affecting the adoption of e-banking in China than those currently understood. Through an in-depth case study, this study indicates that the growth of e-banking in China is mainly driven by the competitive pressure created by the foreign banks and the strong support from the Chinese government. For the company under study, the e-banking adoption is also driven by the top management support, the availability of the resources within the company and the perceived benefits. Issues related to limited infrastructure and immature legal framework to protect e-banking customers have been identified in this study, but they can arguably be addressed through further support from the government. However, addressing issues related to reluctance of banks' customers to use e-banking services due to distrustful culture and high uncertainty avoidance among the Chinese society will be challenging.

In the next section, an overview of the e-banking development in China is presented. Then the research framework and the research method used in this study are outlined, followed by the discussion of the participating organization, the e-banking initiatives currently employed, benefits and issues/barriers experienced. Finally, some implications of the findings and possible future studies are highlighted to conclude the paper.

\section{E-Banking Development in China}

As a large and typical developing country with an ambition to become one of the world's economic superpowers, China understands the importance of EC and has put a significant effort towards developing various EC initiatives including e-banking within the banking sector. Expanding from large cities such as Beijing, Shanghai and Guangzhou to coastal and inland big cities [10], the Chinese EC market has been growing rapidly and is predicted to reach $\$ 654.3$ billion by 2010 [11].

In order to address the escalating competition brought by the opening of the banking sector to foreign players, China's domestic banks are currently being proactive in devising and implementing strategies to advance their e-banking products and services [7]. The first generation of electronic banking was introduced by the China Merchant bank in 1997, in the form of internet payment system. Other major banks followed and introduced the same system between 1998 and 1999 [3]. Online banking services with rudimentary functionalities such as electronic bill payment and fund management were then gradually made available to the retail and corporate customers between 1999 and 2001.

As economies further developed and EC activities grew, the demand for more e-banking functionalities increased dramatically, promoting another round of ebanking service development among the Chinese domestic banks around 2001 [7, 12]. The second generation e-banking, which addresses the demand for increased sophistication in wealth management, provides additional functions that would facilitate investment activities such as the purchase and sale of stocks, currencies and mutual funds. Meanwhile, the basic asset management functionalities such as bill 
payment and fund transfer were also redeveloped to improve usability and convenience. More stringent security measures such as the deployment of USB security token, known as "U Shield" was rolled out in 2002, amid the widespread concern about the reliability and security of e-banking services. According to the latest research report on electronic banking conducted by the China Financial Certification Authority, around $20 \%$ of bank account holders has adopted e-banking in the urban areas, while around $40 \%$ of corporate account holders conducts their transactions online in 2008 [12].

Although e-banking in China has experienced a significant growth in the past several years, it is still regarded in its early stage of development compared to the e-banking adoption and utilisation rate in the developed nations $[4,8]$. There are major problems that impede the growth of e-banking which include the lack of standard legal system, the inability to develop technology infrastructure at a compatible pace with China's e-banking development needs, and low acceptance of e-banking by the Chinese community in general $[3,4,8]$.

\section{Research framework}

To explore the key drivers and barriers to e-banking adoption in China, this study is guided by the technology-organization-environment framework proposed by Tornatzky and Fleischer [18] which is designed for studying the likelihood of adoption success of technology innovations. This framework is a comprehensive and well received framework in the context of innovation adoption by organizations and has been used in many studies [1316]. According to Tornatzky and Fleischer [18], technology adoption within an organization is influenced by factors pertaining to the technological context, the organizational context, and the external environment.

Based on this, we developed our research framework to summarize possible key factors affecting e-banking adoption as shown in Figure 1. The environmental context refers to the external environment in which an organization operates and its condition for supporting the development of e-banking services, while the organizational context refers to the organization's characteristics that influence its ability to adopt and use e-banking. The technological context refers to adopter's perception of e-banking attributes $[13,15,17-18]$. Typical characteristics of technology considered in technology adoption studies are based on Roger's diffusion of innovation theory [17] which include relative advantages (perceived benefits), compatibility, trialability, complexity and perceived risks) $[13,14,17]$. For each context, various factors have been identified from the literature but only those that are considered relevant for e-banking adoption are included in the framework. Details of factors considered in this study are discussed below.

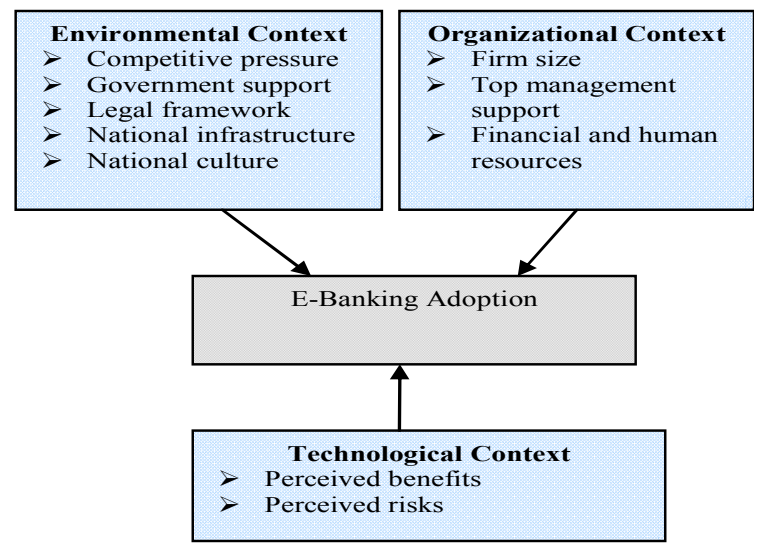

Figure 1: Research Framework (adapted from [7, $14,18])$

\subsection{Technological Context}

It appears that there is a lack of consensus on what factors belong to this context. For example, one study [13] includes technology competence covering existing technology infrastructure and skills to utilize the technology in this context, while other studies $[14,15]$ consider some relevant characteristics of technology. To avoid overlapping between technology and organizational contexts, in our framework we only consider the relevant attributes of e-banking [14]. We consider factors related to technology competence are more relevant to the organisational context. In addition, only perceived benefits and perceived risks are considered in this study. Since e-banking investment was found not to be correlated with IT maturity (IT management sophistication) [7], we consider compatibility and complexity to be irrelevant in the context of e-banking adoption.

\section{Perceived benefits}

Perceived benefits of e-banking cover both direct and indirect benefits for the banking institutions. Direct benefits include the savings on operational cost, improved organisational functionality, productivity gain, improved efficiency and increased profitability. Indirect benefits include the opportunity or intangible benefits such as improved customer's satisfaction through improved services, improved banking experience and fulfilment of their changing needs and lifestyle [7, 20, 21].

Perceived risks 
One of the important risks faced by banking institutions in offering e-banking services is the customers' resistance to use the services which significantly hinder the growth of e-banking [3, 4]. Issues related to security have always been a concern when dealing with technologies related to online transactions such as e-banking [14, 17]. Therefore, the perception of the risks regarding e-banking is expected to influence the adoption and further growth.

\subsection{Organizational Context}

Organizations are different in their inclination to adopt innovation technology [20, 30, 31], influenced by a number of factors. In our framework, we include three factors as discussed below.

\section{Firm Size}

Firm size has been widely recognized as an important factor determining an organization's ability to adopt a new innovation as well as capitalizing on its benefits [13, 38-40]. Typically, large organizations have the resources and skills to adopt new technologies and have enough business volume to justify the investment. Therefore, it is also expected to affect the adoption of e-banking by banking institutions.

\section{Financial and human resources}

Financial resources are an important factor in facilitating innovation adoption for any organization and they are often correlated with the firm size [20,21]. Therefore, it is expected that the availability of financial resources within the adopting firms is important for e-banking adoption. These resources enable banking institutions to obtain human related resources including the required skills and expertise to develop and support e-banking services.

\section{Top management support}

Top management of an organization is also commonly identified as an important factor for any technology adoption within an organization. If top management is assertive in their decision making regarding e-banking adoption and committed to it, the adoption is likely to take place. In addition, with the top management support through the provision of the required resources, organization's inclination to adopt e-banking or any new technology will be improved [20, 27, 30, 31].

\subsection{Environmental Context}

Based on our previous study related to technology adoption in developing countries [46], we identified that factors related to the environmental context play a crucial role in technology adoption and some factors in this category are arguably more influential than others, especially when countries under study have an authoritative government leadership. Five factors relevant for e-banking adoption are included in our framework as briefly outlined below.

\section{Competitive pressure}

Competitive pressure can strongly influence any bank to develop and adopt e-banking initiatives and it may affect the bank's perception towards e-banking services as implied in previous studies [35-37].

\section{Government Support}

Government can either directly or indirectly affect the adoption of e-banking in terms of creating a favourable environment and impetus for banking institutions and their customers so that the services can be diffused with the community [20-23].

\section{Legal Frameworks}

The existence and maturity of EC legal frameworks within a country influence the diffusion of online transactions including e-banking as demonstrated in various studies [see for example 24-26].

\section{The national IT infrastructure}

National IT infrastructure is a major factor that supports the adoption of e-banking as the case for other EC initiatives. Without an adequate development level and quality of a nation's IT infrastructure, e-banking adoption and use cannot flourish [27, 28].

\section{National culture}

Some exploratory studies of developing countries $[28,29]$ have suggested that the unique national culture in some Asian countries is one of the major factors that continue to impede and constrain the development of EC including e-banking. Therefore, national culture is included in our framework and is expected to have an effect on the adoption of e-banking.

\section{Research Method}

In this study, a single case study approach was employed to explore and gain an initial, in-depth understanding of the e-banking adoption in China from the perspective of the banking institution. This approach allows a contemporary issue to be examined in a great detail and requires no control over the phenomena under investigation. In addition, this study is considered a revelatory case as no study has been done in relation to assessing the e-banking adoption situation in China through an in-depth case study from a state-owned bank's perspective [44]. The case organization is one of the big four banks in China and, therefore, its experience with e-banking adoption is 
likely to be representative of the adoption situation among the domestic banks in China.

Data were collected using semi-structured interviews and organization document analysis in July 2007. We selected managers who are believed to be knowledgeable about the EC adoption and e-banking initiative within the case organization and therefore can offer the organization's view. Based on our selection criteria, three managers were involved in the case study, as shown in Table 1.

Table 1: Overview of Case Study Participants

\begin{tabular}{|l|l|}
\hline Participant & Brief Description / Role \\
Manager & $\begin{array}{l}\text { The senior manager interviewed in this } \\
\text { study is responsible for developing and } \\
\text { managing organizational clients }\end{array}$ \\
\hline $\begin{array}{l}\text { Director of } \\
\text { Department }\end{array}$ & $\begin{array}{l}\text { With the increasing adoption of EC, the } \\
\text { EC department was established. The } \\
\text { director of EC department is responsible } \\
\text { for EC strategy and development } \\
\text { including e-banking. }\end{array}$ \\
\hline $\begin{array}{l}\text { Branch } \\
\text { Manager }\end{array}$ & $\begin{array}{l}\text { The branch director is responsible for the } \\
\text { management and performance of the } \\
\text { branch }\end{array}$ \\
\hline
\end{tabular}

The unit of analysis is the organization under study. Interviews were recorded and then transcribed for analysis. To corroborate the data collected during the interviews and to enhance the findings, relevant organizational documents were also requested and analyzed. Correspondence via email was maintained with participants and each of them reviewed the interview transcription and summary of the findings. Transcribed interview data and organizational documentation were analyzed using a qualitative data analysis technique [44, 45], employing open, axial and selective coding techniques. Various key points identified from the case study were then discussed and presented within the research framework.

\section{The Participating Organization}

China Financial Institution (CFI) (a pseudonym), one of the 'Big Four' state-owned banks in China was chosen in this study. It is a leading bank in China possessing extensive strength in corporate and consumer banking, as well as treasury operations. It was incorporated in China in 1954 with a head office in Beijing. As one of the leading banks in the domestic banking sector, the CFI Corporation retains leadership roles in key market segments in the areas of corporate banking, personal banking and treasury operations. It continues to pursue innovative banking services such as electronic banking to stay in a competitive edge and it has an extensive network in China, with approximately 14,250 branch outlets and 1,220 selfservice banking centres, and 16,563 ATMs. CFI has also expanded its overseas branches in Hong Kong, Singapore, Frankfurt (Germany), Johannesburg (South Africa), Tokyo (Japan) and Seoul (Korea), and set up representative offices in London and New York. CFI currently has over 300,000 employees to serve 150 million active personal deposit accounts, 1.5 million high net-worth personal customers, 99 largest enterprises in China.

Recognising the fact that the large number of population in China brings a heavy service pressure to China's banking industry, which may result in several hours of waiting in a queue for customers to do simple transactions, there has been a strong push from the Chinese Government to promote e-banking development in China, as the economy is developing rapidly. In addition, the competition created by the foreign banks with relatively higher EC capabilities has driven domestic banks to actively pursue EC. Therefore, CFI has initiated a number of EC initiatives in the last few years including internet banking, customized professional financial services for VIP members, mobile banking, internet payment services, and a wide range of security protection methods for online transactions. These EC initiatives have been developed following the guidelines proposed by government and CFI EC department, which are, in turn, developed based on the experience of successful foreign banks.

CFI Corporation launched its e-banking services in mainland China in August 2003, which provide its customers new ways of performing banking transactions. CFI has recently described its e-banking services as the core strength and foundation to its business. To achieve its goal of becoming a leader in ebanking, CFI has strengthened its online management team, encouraged employee training, improved marketing strategies and enhanced customer outreach programs. At the time of the study, CFI has obtained 40.29 million e-banking customers (including 10.89 million Internet banking and 7.2 million mobile phone banking customers) and 1.51 million equity and funds investment customers.

\section{Case Study Findings and Discussion}

We discuss the case study findings in this section under three categories: technological, organizational and environmental context.

\subsection{Technological Context}

\section{Perceived benefits fundamental to e-banking adoption}

Our case study indicates that perceived benefits obtainable from the e-banking initiatives are one of the 
fundamental reasons for its adoption by CFI, which confirms the finding of the previous studies [eg. 1, 4, 7]. The main benefits include improvements in customer services, business efficiencies and cost reductions. In terms of customer services, by introducing e-banking services, CFI was able to successfully reduce the counter pressure and customer waiting time by diverting a portion of customers to the electronic service medium. It also offers convenience, ease of use and ease of access of banking services. Moreover, e-banking has enabled the establishment of more efficient and effective business processes and allowed CFI to successfully address the rapidly increasing retail banking transaction volumes without significant increases in staffing costs, as revealed in the following interview excerpt:

"The adoption of the e-banking has helped us decreased the counter's pressure in a great extent. At the same time, if we didn't have e-banking, we would employ more staff to serve the constantly increasing number of customers. So currently, the adoption of $e$ banking prevents us from employing more employees. We also are expecting to cut the number of employees to improve organization efficiency if the use of our ebanking is continually increasing". (Director of Department of EC)

Further e-banking growth can be hindered by customers' reluctance to use the services

Despite the benefits e-banking, CFI has also experienced the reluctance of some customers to use the e-banking services. Although CFI has attempted to mitigate this risk through various initiatives including the provision of a demo system to allow users to have a trial on the use of e-banking and various marketing efforts, consistent with the previous studies [3, 4] our study shows that there has still been a concern among some customers regarding the security of e-banking services. This security concern seems to have negated the value of e-banking in terms of convenience, ease of use, access to services anytime anywhere. Given the open, interactive nature of the EC technologies which are the backbone of e-banking services, security is difficult to ensure especially in a developing country like China. CFI's e-banking system has indeed suffered multiple large scale breaches despite the current security measures implemented. Such incidents have lowered consumer confidence and, thus, hindered ebanking growth.

Our study also shows that unauthorized use of personal information to conduct e-banking activities and the increasing number of high-profile Internet security breaches are becoming an urgent issue for all Chinese banks to address. Without effectively guaranteeing the network security, consumer confidence and demand for e-banking services will remain low and, consequently, the e-banking use will be restricted. All of interviewees in this study have confirmed that the security issue has been a significant inhibitor for CFI's e-banking growth.

"Theft of information, data breaches and internetbased attacks have seriously affected customers purchasing, payment, and online transaction behaviours. We have lost our customers due to their security concerns and lack of trust with our e-banking systems." (Director of EC Department)

\subsection{Organizational Context}

Firm size facilitates the required financial and human resources in e-banking adoption

As one of the four largest state-owned banks with a strong government support, CFI has the required financial and human resources to support various ebanking initiatives. Unlike the concern raised in a previous study [7] that large banks in China are usually more conservative and slow in technology adoption, our study indicates that CFI has been proactive in exploiting EC initiatives including e-banking to stay competitive with other banks especially foreign banks. This finding confirms the important role firm size, financial resources and human resources in facilitating e-banking adoption as indicated in other studies of technology adoption [eg. 7, 13, 14, 16].

Top management support critical to e-banking success

The case study confirms many previous studies [eg. 13] regarding the importance of top management support in technology adoption such as e-banking. Top management support was found to be the main enabler of the success of e-banking adoption in CFI. As a stateowned enterprise, CFI retains the bureaucratic characteristic in its organizational structure. Strong top management support becomes an essential requirement when the e-banking initiatives have to be implemented through an exceedingly complex web of hierarchies that exist in CFI. With a strong and proactive top management support, CFI was able to launch deep and large scale organizational change programs to facilitate e-banking.

\subsection{Environmental Context}

\section{Competition pressure drives e-banking investments}

Based on the analysis of the case study, the competition from both foreign and domestic private banks appears to be the most important driver for CFI to develop its e-banking capabilities. The foreign- 
funded banks are especially competitive in securing corporate clients over the Chinese banks because they are perceived to offer better services and more stringent security measures given their longer experience in e-banking development. In addition, the competition for retail clients is also furious among the domestic banks. This finding is in line with previous studies [eg. 3, 7, 13] that organizations commonly adopt technological innovations to offer better quality products and services to satisfy customers as a response to competitive pressure from the environment.

According to the Senior Manager of CFI, service offerings such as Internet banking and USB security token have become standard practices among the Chinese banks. In order to stand-out among the competitors, an increasing amount of e-banking investments is being committed by various banks, which has consequently propelled its development within the Chinese banking industry. CFI has put more investments in developing better, consumer-oriented products and services related to e-banking with improved security features to attract potential customers. They include the provision of eAlertService to remind customer of any banking and investment transactions required and other personal appointment and the use of e-Cert for individual and organizational clients or the use of two-factor authentication to enhance the security feature in performing e-banking activities.

\section{Government support enables smoother e-banking adoption}

In addition to the competitive pressure, the case study suggests that the government support is also a strong driver for e-banking adoption in China. The government support is manifested in two ways. Firstly, the Chinese Government is establishing an EC-friendly environment in China. Heavy investments have been committed by the Chinese government in recent years to revamp the national ICT and logistic infrastructures. New EC laws and regulations have also been passed and adjusted to provide legal protections for $\mathrm{EC}$ activities in general. Secondly, the government also directly offers financial incentives to promote ebanking adoption. According to the interviewees, CFI and the other state-owned banks are receiving government financial support for organizational restructuring aimed at improving their e-banking adoption. In particular, the Senior Manager interviewed asserts that in 2004, Chinese government invested USD 45 billion in CFI and Bank of China alone. The large scale "blood transfusion" from the government, has greatly optimized CFI's organizational operations and established a stable base for the development of e-banking and other EC initiatives through a series of Golden projects. This supports the findings reported in $[13,16]$ about the importance of regulatory support from the government and complements the finding of the previous study [7] exploring factors affecting Internet banking investment by Chinese banks.

\section{National EC infrastructure inadequate in supporting e-banking development}

Despite the recent improvements made on the national infrastructure, the overall EC infrastructure in China remains inadequate. The case study suggests that the poor quality of telecommunication network service is a major obstacle for CFI to effectively deliver some services such as mobile banking. The current telecommunication network's inability to support the bandwidth and security demand of these new ebanking applications has significantly restricted their wide use among the consumers, which consequently limits banks' ability for further growth and development. This observation has not been addressed in those related previous studies in China $[3,4,7]$.

\section{The lack of rule of law increases customers' reluctance to use e-banking}

The study by Tan and Ouyang [25] at the early stage of e-banking development shows that the legislation is an initial barrier that influences e-banking adoption in China. However, the findings from this case study show that although EC legislation is still one of the obstacles for the e-banking development within the banking industry, the main issue is actually less about the legislations itself, but more about the lack of rule of law. The lack of transparency and fairness in the Chinese jurisdiction systems has caused wide-spread distrust towards the state's ability to fairly enforce the legislations in place. The distrust is especially prominent in newly introduced legislations such as EC laws and regulations. Despite the existence of relevant EC laws and regulations to protect ebanking users, the Branch Manager explains that Chinese customers are generally sceptical of the state's ability to protect their interests and to ensure the security of online activities.

"One of the main issues we currently have is our customers' perception of the legislations. As we know the legislations are already put in place, so we are constantly convincing them that the e-banking is well protected by the legislation. However, their response is very negative. They do not know or have never heard about the legislations that have been in place, or they do not even trust the legislations as they think the legislations are not mature." (Branch Manager) 
Therefore, in order to successfully facilitate ebanking adoption in China, the Chinese government needs to urgently establish a clear set of rule of law to restore people's confidence in the Chinese legal system.

\section{High uncertainty avoidance and lack of trust among customers severely impede e-banking growth}

The traumatic events in the recent Chinese history have significant impact on the Chinese culture. The value system, behaviour and attitude of the Chinese people have changed from a trustful and peaceful nature to a culture that is characterised by distrust and high uncertainty avoidance focused on selfpreservation. Such culture makes the promotion of ebanking extremely difficult for banks. Given their distrustful nature, the Chinese consumers are instinctively suspicious of anything that is new and unproven. The fact that the e-banking deals directly with the personal wealth of the consumers further elevated the feeling of distrust among the Chinese people. As a result, the Chinese banks are facing significantly greater challenges in promoting e-banking services compared to their counterparts in the developed nations. This situation is highlighted by the Branch Manager during his interview:

“... when we are selling e-banking products, we offer promotional offers such as a 50 Yuan Telephone card for free for each new customer. But our customers sometimes, would think this is a trick we set there in order to make them pay more, so they are very careful with these promotions..."

As a result of such a distrustful culture, many Chinese banks have not been successfully attracted new customers despite their significant marketing efforts. With the distrustful culture deeply rooted into the mind of the Chinese consumers, Chinese banks are facing an uphill battle overcoming the effect of the Chinese culture and convincing the consumers' of their credibility. This observation reinforces the findings in the previous studies $[3,4]$ assessing the consumers' perception of e-banking in China.

\section{Conclusion}

Guided by the technology-organizationenvironment (TOE) framework, this study has identified a number of barriers to e-banking adoption, in addition to the key drivers as summarized in Table 2. Overall, consistent with other studies on technology adoption in developing countries, most barriers to ebanking identified in this study are related to the environmental context, specifically those related to infrastructure, legal framework and cultural attributes that lead to reluctance of customers to use e-banking services. Interestingly, no problems related to the organizational context were identified in this study.

Table 2: Summary of Key Drivers and Barriers

\begin{tabular}{|c|c|}
\hline Drivers & Barriers \\
\hline \multicolumn{2}{|l|}{ Technological Context } \\
\hline Perceived benefits & $\begin{array}{l}\text { Customers' reluctance } \\
\text { customers due to security } \\
\text { concerns }\end{array}$ \\
\hline \multicolumn{2}{|l|}{ Organizational Context } \\
\hline \multicolumn{2}{|l|}{ Firms size } \\
\hline \multicolumn{2}{|l|}{ Top management support } \\
\hline \multicolumn{2}{|l|}{$\begin{array}{l}\text { Availability of financial and } \\
\text { human resources }\end{array}$} \\
\hline \multicolumn{2}{|l|}{ Environmental Context } \\
\hline Competitive pressure & $\begin{array}{l}\text { Limited infrastructure for } \\
\text { move advanced e-banking } \\
\text { applications }\end{array}$ \\
\hline \multirow[t]{2}{*}{ Strong government support } & Immature legal framework \\
\hline & $\begin{array}{l}\text { High uncertainty } \\
\text { avoidance and lack of trust }\end{array}$ \\
\hline
\end{tabular}

The findings of this study offer additional insights into the current e-banking adoption situation and its implications for e-banking growth in China as an example of a developing country. Furthermore, the understanding of the barriers to e-banking adoption identified in this study may help identify the best course of actions to promote its development. It will also be valuable to the other developing countries to increase their awareness and understanding of ebanking benefits and possible issues/barriers that they need to face in the course its adoption.

There are some implications of this study for both researchers and practitioners in the area of e-banking adoption and other EC technology adoption by developing countries. Firstly, the study shows the usefulness of studying the technology adoption from a service provider point of view to complement the understanding obtained from the consumer point of view. Most adoption studies regarding consumeroriented EC such as online shopping, mobile commerce adoption, internet banking and so on, have generally been conducted from the consumers' point of view. In fact, the behaviour and the perception of consumers can be better understood by including the view of the service providers as well.

Furthermore, the study shows the importance of addressing the influence of the state government, which is unlikely to be achieved through a study from a consumer point of view. Authoritarian government has a strong control over the every aspect of the country as demonstrated in the e-banking case in this study. While this may have a good impact on the development of the initiative through infrastructure and regulation development and financial support and it 
may also hinder its growth by establishing strict Internet content regulations and monitoring procedures.

The study findings also imply that more efforts are still required by the Chinese government to devise and promote legislations to protect users of e-banking and other EC initiatives in general in order to increase the society's awareness of the legislations and how they are being enforced. In particular, more effective fraud prevention methods are still required to build the community's trust on e-banking and other consumer oriented EC initiatives.

To improve the generalizability of the study findings which is limited by the data obtained from one state-owned bank focusing on e-banking initiatives, further research could be conducted with some private banks in China to explore their adoption experience with e-banking. Furthermore, a better understanding is still required about the dynamics between the state and the adoption of e-banking and possibly other EC initiatives in China. Specifically, as China is becoming increasingly open to the outside world, its culture is dynamically changing. Different generations hold significantly different cultural values and it may have significant implications on EC initiative adoption and management. In addition, future research into the adoption of other EC initiatives in other industry sectors in China and other developing countries particularly within the Asia Pacific region would be valuable to complement this study's findings. Such studies would also provide the replication logic necessary to improve the generalizability of the current findings. This understanding will be valuable in devising appropriate strategies for promoting EC adoption within the developing countries in general, particularly those within the Asia Pacific region.

\section{References}

1. Osho, G.S., How technology is breaking traditional barriers in the banking industry: Evidence from financial management perspective. European Journal of Economics, Finance and Administrative Sciences, 2008(11): p. 15-21.

2. Turban, E., et al., Electronic commerce: a managerial perspective. 4th Edition ed. 2008: Prentice Hall.

3. Laforet, S. and X. Li, Consumers' attitudes towards online and mobile banking in China. International Journal of Bank Marketing, 2005. 23(5): p. 362-380.

4. Zhao, A.L., et al., Perceived risk and Chinese consumers' internet banking service adoption. International Journal of Bank Marketing, 2008. 26(7): p. 505-525.

5. Mann, C.L., Electronic Commerce in Developing Countries: Issues for Domestic Policy and WTO
Negotiations, in Services in the International Economy: Measurement, Modelling, Sectoral and Country studies and issues in the World Services Negotiations, R. Stern, Editor. 2000, Institute for International Economics.

6. Qureshi, S. and A. Davis. Overcoming the Digital Divide through Electronic Commerce: Harnessing opportunities in IT for Development. in 40th Hawaii International Conference on System Sciences. 2007. Hawaii.

7. Lu, M.-t., et al., Internet banking: strategic response to the accession of WTO by Chinese banks. Industrial Management \& Data Systems, 2005. 105(4): p. 429-440.

8. Rotchanakitumnuai, S. and M. Speece, Barriers to Internet banking adoption: a qualitative study among corporate customers in Thailand. International Journal of Bank Marketing, 2003: p. 312-323.

9. Xu, X., Corporate Restructuring of Industrial and Commercial Bank of China (ICBC), Motivators and Impacts, in Management. 2006, The University of Nottingham: Nottingham.

10. Inc, M.E., China Market Report. 2006, Morgan, Evan \& Company, Inc. p. 1-88.

11. Tan, J., K. Tyler, and A. Manica, Business-to-business adoption of eCommerce in China. Information \& Management, 2007. 44: p. 332-351.

12. CFCA, 2008 Online Banking report. 2008, China Financial Certification Authority.

13. Salwani, M.I., et al., E-commerce usage and business performance in the Malaysian tourism sector: empirical analysis. Information Management \& Computer Security, 2009. 17(2): p. 166-185.

14. Chang, I.-C., et al., Factors affecting the adoption of electronic signature: Executives' perspective of hospital information department. Decision Support Systems, 2007. 44: p. 350-359.

15. Ellis, J. and J.-P.V. Belle. Open source software adoption by South African SMEs: Barriers and Enablers. in SACLA. 2009. Mpekweni Beach Resort, South Africa.

16. Zhu, K., K.L. Kraemer, and S. Xu, The process of innovation assimilation by firms in different countries: $A$ technology diffusion perspective on E-Business. Management science, 2006. 52(10): p. 1557-1576.

17. Rogers, E.M., Diffusion of Innovations. 5th ed. 2003, New York: Free Press.

18. Tornatzky, L.G. and M. Fleischer, The Process of Technology Innovation. 1990, Lexington, MA: Lexington Books.

19. Thong, J.Y.L. and C.S. Yap, CEO characteristics, organisational characteristics, and information technology adoption in small business. Omega, 1995. 23(4): p. 429-442.

20. Iacovou, C.L., I. Benbasat, and D. A.S., Electronic data interchange and small organisations: Adoption and 
Impact of Technology. MIS Quarterly, 1995. 19(4): p. 465-485.

21. Kuan, K.K.Y. and P.Y.K. Chau, A Perception-based model for EDI adoption in small business using a Technology-Organisation-Environment Framework. Information and Management, 2001. 35: p. 507-512.

22. Gibbs, J.L. and K.L. Kraemer, A cross-country investigation of the determinants of scope of e-Commerce use: An institutional approach. Electronic Markets, 2004. 14(2): p. 124-137.

23. Tan, Z. and O. Wu, Diffusion and Impacts of the Internet and E-commerce in China. Globalisation and Electronic Commerce, 2004. 14(1): p. 25-35.

24. Martinsons, M.G., Electronic commerce in China: emerging success stories. Information \& Management, 2001. 39: p. 571-579.

25. Tan, Z. and O. Wu, Global and National Factors Affecting E-commerce Diffusion in China, in Globalisation and E-Commerce. 2002, Centre for research on information technology and organisations: Irvine.

26. Trappey, C.V. and A.J.C. Trappey, Electronic commerce in Greater China. Industrial Management \& Data Systems, 2001. 101(5): p. 201-209.

27. Scupola, A., The Adoption of Internet Commerce by SMEs in the South of Italy: An Environmental, Technological and Organizational Perspective. Journal of Global Information Technology Management, 2003. 6(1): p. 51-71.

28. Efendioglu, A.M. and V. F.Yip, Chinese culture and ecommerce: an exploratory study. Interacting with Computers, 2004. 16: p. 45-62.

29. Vatanasakdakul, S. Reshaping e-commerce in Thailand: An exploratory study of Internet technology for inter-firm communication adoption in the Thai tourism industry from a cultural fit perspective. in Australasian Conference on Information Systems. Dec 2006. Adelaide.

30. Grover, V., An Empirical derived model for the adoption of customer-based inter-organisational systems. Decision Science, 1993. 24: p. 603-638.

31. C.W., C. and Kumar R. L., Electronic data interchange: A multidisciplinary investigation using grounded theory. Information and Management, 1998: p. 75-79.

32. Chen, S. and J. Ning, Constraints on E-Commerce in less developed countries: the case of China. Electronic Commerce Research, 2002. 2: p. 31-42.

33. Chitura, T., et al., Barriers to electronic commerce adoption in small and medium enterprises: A critical literature review. Journal of Internet Banking and Commerce, 2008. 13(2).

34. Uzoka, F.-M.E., A.P. Shemi, and G.G. Seleka, Behaviourla Influences on E-Commerce adoption in a Developing Country Context. The Electronic Journal on
Information Systems in Developing Countries, 2007. 31(4): p. 1-15.

35. Gibbs, J., K.L. Kraemer, and J. Dedrick, Environment and Policy factors shaping e-Commerce diffusion: A cross-country comparison. The information society, 2003. 19(1): p. 5-18.

36. Quaddus, M. and G. Hofmeyer, An investigation into the factors influencing the adoption of $B 2 B$ trading exchanges in small businesses. European Journal of Information Systems, 2007. 16: p. 202-215.

37. Zhu, K., K. Kraemer, and S. Xu, Electronic business adoption by European firms: a cross-country assessment of the facilitators and inhibitors. European Journal of Information Systems, 2003. 12: p. 251-268.

38. Andersen, K.V., N. Bjorn-Anderson, and J. Dedrick, Governance initiatives creating a demand driven eCommerce approach: The case of Denmark. The information society, 2003. 19: p. 98-105.

39. Bertschek, I. and H. Fryges, The adoption of business-tobusiness E-Commerce: Empirical Evidence for German companies. 2002, Centre for European Economic Research.

40. Stockdale, R. and C. Standing, A classification model to support SME e-Commerce adoption initiatives. Journal of Small Business and Enterprise Development, 2006. 13(3): p. 381-394.

41. Hsu, P.-F., K.L. Kraemer, and D. Dunkle, Determinants of E-Business use in U.S. Firms. International Journal of Electronic Commerce, 2006. 10(4): p. 9-45.

42. Anderson, J.G., Social, ethical and legal barriers to Ehealth. International Journal of Medical Informatics, 2007. 76: p. 480-483.

43. Parker, C. and T. Castleman. Why should small firms adopt eBusiness? A Framework for Understanding the SME eBusiness Context. in 18th Australasian conference on information systems. 2007. Toowoomba.

44. Yin, R.K., Case study research: design and methods. Third Edition ed. Applied Social Research Methods. Vol. 5. 2003: Sage Publications.

45. Miles, M.B. and A.M. Huberman, Qualitative and Quantitative Approaches. 4th Edition ed. 1994: Allyn and Bacon.

46. Sherah Kurnia, Exploring E-Commerce Readiness in China: The Case of the Grocery Industry. in Proceedings of the 41st Annual Hawaii International Conference on System Sciences (HICSS 2008), 2008 